\title{
Inequality in Intercollegiate Athletics: Origins, Trends and Policies
}

\author{
Andrew Zimbalist \\ Smith College
}

\begin{abstract}
In this paper, the author provides an overview of economic inequality in intercollegiate athletics, tracing it from its origins in the late 19th century, through home rule, the introduction of the NCAA's national broadcasting policy and its subsequent regionalization after Oklahoma v. NCAA, conference realignments, RSNs, the BCS and NCAA distribution policies. The paper argues that the current economic situation and the growing inequality is unsustainable and that policies to reverse the course are necessary. Policies to moderate inequality will not only assist in promoting financial stability but will also blunt the all-out drive to win and thereby help to reestablish the primacy of education in intercollegiate athletics.
\end{abstract}

Inequality in intercollegiate athletics began when intercollegiate athletics began. The first college sports contest, the rowing match between the Harvard and Yale boat clubs at Lake Winnipesaukee in 1852, was infused with commercial motives. The manager of the Boston, Concord and Montreal Railroad organized the event to advertise its rail service to wealthy clientele in New York and Boston. The railroad company lured the boat teams to the match with "unlimited alcohol" and "lavish prizes." The first known college sports eligibility abuse came three years later at another Harvard/Yale meet, when the Harvard team's coxswain was not a student.

In 1862, the first Morrill Land Grant College Act was passed to provide states with federal land on which to establish state schools to teach agriculture, engineering, and military tactics. Many states took advantage of the program to establish universities, even when they did not have sufficient qualified population to enroll in postsecondary education. Together with liberal arts colleges, technical institutes, and preexisting state universities, there grew up an intense competition to fill the appreciable excess supply of available beds at U.S. colleges. In this context, schools sought whatever competitive advantage they could identify. Intercollegiate sports came to be seen as central to promoting a college to prospective applicants. Allen Sack and Ellen Staurowsky (1998) write:

In the late 1800 s few campus activities could better meet that need than intercollegiate sport. Nothing could better attract the attention of mass media, and nothing had a greater appeal to the practical-minded business leaders who 
provided financial support and who increasingly came to dominate academe's governing boards. (p. 20)

In 1890, Woodrow Wilson, then President of Princeton University, told alumni: "Princeton is noted in this wide world for three things: football, baseball, and collegiate instruction" (Zimbalist, 2001, p. 7).

Rainey Harper, University of Chicago President in the early 1890s, hired former Yale football star Amos Alonzo Stagg to coach football. Harper told Stagg to "develop teams which we can send around the country and knock out all the colleges" (Sack \& Staurowski, 1998, p. 21). Harper reportedly provided Stagg with a trust fund of $\$ 80,000$, originally earmarked for low-income students, for recruiting and subsidizing athletes, and commented, "We will give them a palace, car and a vacation too" (p. 21).

On top of operating expenses, schools also began to lavish resources on athletic fields and stadiums to promote their teams. In 1878, many critics were aghast that Yale rented a field in Hoboken, New Jersey for $\$ 300$ to play Princeton in football. In 1903, Harvard was the first college to build a concrete stadium, designed explicitly for football. Yale followed with the Yale Bowl in 1914, the University of Pennsylvania's Franklin Field was expanded for football in 1922, the University of California at Berkeley built a stadium with a seating capacity of 76,000 in 1923, Baker Field at Columbia University was finished in 1928, and so it went with schools readily raising their football budgets in an effort to stay competitive.

For our purposes, the essence of these practices is that the intercollegiate athletics market was competitive and each of the producers sought advantage from athletic success. The outcome of such a market process, especially one without meaningful regulation, is inequality: strength nourishes strength and weakness feeds weakness.

Although the modalities, manifestations, and magnitudes of this competitive process varied over the years, the fundamental outcome of increasing inequality has remained constant. As NCAA schools moved away from the laissez-faire, home rule period, lesser known or poorly endowed universities protested when new regulations favored their more famous, wealthy competitors. The dissolution of the Sanity Code and, soon thereafter, the principles of NCAA broadcasting policy responded to concerns about growing inequality. The discussion that follows attempts to highlight the key factors, beyond the competitive marketplace, that have promoted the increasing inequality in college sports.

\section{Sources of Inequality}

\section{Broadcasting Policy and Board of Regents v. NCAA}

From 1951 until 1981, the NCAA's basic broadcasting policy was to limit each school to two television appearances per year. ${ }^{1}$ The NCAA skimmed between 4 and $12 \%$ off the top, and the rest was distributed to the colleges whose games were televised, with appearances in a nationally televised game bringing around $30 \%$ more than a regionally televised game (Byers, 1995). However effective this policy may have been in the aggregate, it left few satisfied customers. The big-time football programs wanted more exposure and the small programs wanted greater revenue sharing. 
At a special summer convention in 1973, the Association moved to placate the big-time colleges by breaking into three divisions. Each division would operate with significant autonomy, setting its own policies with regard to scholarship limits or number of coaches per sport. The NCAA Council would now have eight representatives from Division I and only three each from Divisions II and III. The Association attempted to mollify Divisions II and III by giving each its own football championship televised by $\mathrm{ABC}$. In recognition of this, the two lower divisions would be allocated $\$ 500,000$ of the new $\$ 16$ million TV contract.

Conspicuously omitted from the benefits of this juggling act were the weaker Division I institutions, such as California State University at Long Beach which did not appear on television and, in 1974, averaged fewer than 6,000 spectators per game. It is not surprising that Cal State at Long Beach President Stephen Horn, in July 1975 , proposed that $50 \%$ of all television revenues (including bowl games) be divided equally among NCAA members not appearing on television. Cries of socialism resounded throughout the Association. Horn's plan was rejected, but its consideration sufficiently discombobulated the big-time schools that it stimulated new centrifugal forces within the Association.

Concerned by the implications of the Horn plan, 25 individuals representing schools from seven major football conferences as well as Notre Dame and Penn State met in Chicago on October 15, 1975. A steering committee was formed that eventually recommended the partitioning of Division I into two echelons; the upper echelon would be composed of the top 70 or 80 football schools, and these schools would be able largely to self-govern. When no such reorganization occurred at the NCAA's 1976 convention, the steering committee prepared the launch of the College Football Association (CFA).

The CFA's first meeting was held in June 1977 with 61 members. As little more than a lobbying bloc within the NCAA, the CFA had little to show for its efforts after two years of operation. The share of television appearances by CFA members dropped from $67 \%$ in 1977 to $55 \%$ in 1979; meanwhile, TV ratings for college football fell from 14.1 to 11.4 (Smith, 1994, p. 78). CFA members naturally linked these two developments, arguing that fans were only interested in watching the top teams on television. The CFA stepped up its lobbying and initiated discussions with the networks for a separate TV contract.

In 1981, the CFA reached preliminary agreement with NBC for a four-year deal worth $\$ 180$ million. The CFA hierarchy had only to persuade its rank-and-file to bolt the NCAA television structure. The prospective CFA deal was enough to wrest an important concession out of the NCAA at its 1981 convention-the Association voted to split Division I into two parts, A and AA, and to allow each to control its own television policy. The top level would now have 105, instead of 180 schools.

The CFA leadership, though, argued that this did not go far enough. The top football schools numbered no more than 80 . Indeed, some ADs and coaches of CFA institutions went further. Oklahoma's head coach, Barry Switzer, stated that what was needed was an Association of the top 40 football colleges. Switzer explained:

We could set our own rules. Maybe give the players $\$ 50$ a day. Get rid of the 95 [football grant-in-aid limit].... I don't care how many coaches Missouri has. If they want 20 , let them have $20 \ldots$ If we're expelled from the NCAA it could enable us to do some things that are realistic (Byers, 1995, p. 277). 
But the concession to subdivide Division I, the increase in the maximum number of yearly TV appearances per school to three, and the handsome new NCAA TV contract with ABC, CBS, and TBS (more than double the previous one with $\mathrm{ABC}$ ) led a majority of the CFA members to stay with the NCAA. Some CFA schools, however, were not willing to go down without a fight. Oklahoma, despite being the preeminent power in college football during the seventies, was earning $\$ 228,035$ from the NCAA in 1979, less than 1\% of the NCAA's total contract with ABC. Oklahoma was not willing to accept the status quo. Neither was the University of Georgia. The two schools filed an antitrust suit against the NCAA at the end of 1981. This suit, after passing through the trial and appeals courts, led to the game changing Board of Regents v. NCAA decision by the Supreme Court in 1984.

While the basic structure of the NCAA television plan remained the same over the years, the restrictions grew less severe. Gradually more broadcasts and more exceptions were allowed. In the last four-year contract with $\mathrm{ABC}, \mathrm{CBS}$, and Turner, ABC and CBS would carry nationally 14 games each, and Turner would show 19 evening games. With exceptions for regional and local games, in 1983 there were 242 games broadcast involving 173 different schools. The rights fees paid to the participating schools were set by the plan and only those schools which were televised received a piece of the $\$ 74.2$ million television revenues in $1983 .{ }^{2}$

In brief, the Supreme Court looked at this information and ruled in a 7-to-2 decision that the NCAA was behaving as a cartel, in illegal restraint of trade. This meant that through its television package, the NCAA was artificially limiting the number and selection of games shown. Thus, if consumers wished to watch the Oklahoma Sooners play more than three times a year, they could not. This restriction lowered consumer welfare and was a violation of Section One of the Sherman Antitrust Act of 1890. In the free marketplace, perhaps there was a television station in Oklahoma that wanted to carry additional Sooner games and that the Oklahoma athletic department was ready to strike a deal with this station. The NCAA policy did not allow this to happen, and it thereby restrained trade and lowered welfare.

Further, the Supreme Court charged the NCAA with price fixing. That is, the price or rights fee received by the producers (the televised football teams) was set ahead of time, largely independent of the quality of the teams or the popularity of the contest (Lawrence, 1987). For instance, in the fall of 1981 there was a televised contest on ABC between USC and Oklahoma, each team was ranked in the top five nationally, and it was carried on over 200 stations. On another weekend that fall ABC televised a game between Appalachian State and the Citadel which was carried on only 4 stations. All four teams received the same rights fees.

The Court was endorsing the economic argument that such interference with the market price would encourage overproduction of football at inferior football schools and underproduction of football at superior schools. Finally, the Court argued that the NCAA TV package represented a group boycott; that is, once the pact with $\mathrm{ABC}, \mathrm{CBS}$, and Turner was signed, there was a de facto boycott by all NCAA members of NBC and other broadcast and cable stations.

The NCAA's defense was that (a) if it allowed too many football games to be broadcast on television, it would threaten live attendance at the games and (b) by spreading television appearances out among the majority of Division I football schools, it allowed television revenues to be distributed more equally among the schools (Dunnavant, 2004). The more even revenue distribution, in turn, promoted 
more equal playing strength among the teams and fostered the amateur spirit by reducing the financial reward received by a school having a top-flight football team.

The Supreme Court's response to the NCAA was, first, that it did not matter if broadcasts lowered live attendance. If fans had a choice, they would choose the option that gave them the most pleasure per dollar. The relevant datum was not whether fewer people were in attendance, but whether the sum of fans in attendance plus fans watching on television would be greater if the TV restrictions were lifted. Further, the Court noted that the NCAA already broadcast its national and regional games at the same time the live games were played. Second, the Court argued that it was not clear that the TV plan promoted competitive balance and suggested there would be more effective ways to do so that would have a less restrictive impact on the number and variety of television broadcasts.

In its majority opinion, however, the Court did not directly address the relevance of promoting the values and institutions of amateurism - an area that received little attention in the NCAA's defense. ${ }^{3}$ In the Court's dissenting opinion, written by Justice White, and joined by Justice Rehnquist, it is maintained that, in supporting the more equal distribution of television exposure and revenues, the NCAA plan reduced the incentive to win. A reduced financial incentive to win, in turn, supported the primacy of academic matters and discouraged commercialism, frenetic recruiting efforts, high salaries for coaches, and so on. Justice White maintained the majority decision treated college sports strictly as a commercial enterprise, and ignored its central purpose as a complement to the academic mission of the university. The open commercialization of college sports, White opined, would only serve to undermine the intended subservient role of athletics in the educational process.

The division within the Supreme Court reflects the inherently hybrid character of intercollegiate athletics, which is, in part, amateur and, in part, intensely commercial. By applying normal standards of free enterprise, the majority of the Court was giving freer rein to the further commercialization of college sports. The resulting potential for heightened revenue, in turn, led universities to devote even greater resources to seeking athletic success.

Of course, had the Supreme Court upheld the NCAA policy, it is possible that another, perhaps more commercialized, scenario would have ensued. The Universities of Oklahoma, Georgia, Notre Dame and many others from the CFA may have seceded from the NCAA and signed their own television agreement. While this would have created a hyper-commercialized sector within college sports, it might also have reduced the commercialization tendencies within the rest of the NCAA.

With the NCAA's TV policy struck down, schools and conferences were left to fend for themselves. The NCAA television cartel was broken. The leading football colleges and conferences were cut free and the weaker football colleges lost the protection of the NCAA plan.

What did happen in the wake of the Supreme Court decision was predictable. In the short run, disorder reigned. Oklahoma, Georgia, Nebraska and USC put their football contests up for sale, but they were disappointed with the networks' offers. Notre Dame got the largest offer, \$20 million, but turned it down. Scurrying about to arrange a deal in time for the 1984 season, the CFA managed to ink one-year deals with $\mathrm{ABC}$ and ESPN worth $\$ 35$ million. In addition to the CFA pact, the Big 10 and Pac-10 signed their own contract with CBS for around $\$ 10$ million. The combined value of the CFA and Big 10/Pac-10 deals was some $60 \%$ below the 
value of the NCAA's 1983 contracts despite the fact that it involved roughly twice as many network games (Porto, 2012, p.74).

Some economists have viewed this outcome as a confirmation of monopoly theory: monopolists artificially lower output below and raise price above competitive levels. Thus, when the NCAA monopoly power in the television market was broken up, the resulting output was higher (almost double the number of televised games) and the price (TV revenue per game) was lower. While this dynamic probably explains part of the price drop in 1984, it is likely that a substantial portion of the drop is attributable to the inexperience and disorganization of the Division I football colleges in negotiating television deals as well as the shortness of time before the 1984 season. Indeed, for 1984 it was not only the revenue per game but the overall revenue from television that had fallen. ${ }^{4}$ There was not, after all, very much competition in 1984-only two groups, the CFA and the Big 10/Pac-10, existed.

Ironically, it was not until the CFA/Big10/Pac-10 duopoly of the 1980s gave way to more competition in the 1990s that television revenue from college football began its next rapid ascent. In 1990, Notre Dame broke from the CFA and signed its own 5-year deal with NBC, worth $\$ 38$ million. Consequent to Notre Dame's withdrawal, the new 5-year deal that the CFA had inked with ABC and ESPN was reduced by $\$ 35$ million down to $\$ 300$ million, which was still $\$ 25$ million more per year than its previous 1987-90 contract.

Notre Dame's bolting from the CFA, however, had a larger significance. It revealed the fragility of the CFA cartel and the potential attractiveness for other schools or conferences to do their own negotiating. Conferences took this message to heart and began discussions with the networks. They were given a basic lesson in television economics. Their rights fees would grow in proportion to the size of their market. Further, the larger was each conference, the fewer would be the number of conferences in Division IA and the lesser the competition. And significantly, the NCAA passed a new rule allowing conferences with at least 12 teams to split into two divisions and hold a championship game.

Not surprisingly, the conferences began to realign and expand to extend their market coverage. The first step was taken by the Big 10, which voted in June 1990 to admit Penn State into its conference. The Atlantic Coast Conference (ACC) added previously independent Florida State. The Southeastern Conference (SEC) expanded to 12 teams and the Big 8 annexed four teams from the Southwest Conference.

Geographically enhanced, the conferences one by one broke off from the CFA cartel and signed their own TV deals. In February 1994, the SEC led the way with an $\$ 85$ million deal with CBS, commencing after the last year (1995-96) of the CFA contract with ABC and ESPN. Three days later the ACC signed up with ABC and ESPN; the next day the Big East inked a deal with CBS and three weeks later the Big 8 entered into a contract with $\mathrm{ABC}$ and Liberty Sports.

The data in Table 1, which draw from various NCAA reports, illustrate the revenue distributional impact of the 1984 Supreme Court decision and the conference restructuring of the 1990s. During the 18 years between 1962 and 1980, there was a steady increase in revenue inequality across the top 150 college athletic programs, with the ratio of the top revenue program to the average revenue program increasing by 0.67 points. During the next 17 year period, 1980-1997, the ratio of the top to average program increased at an accelerated pace, by 1.00 points. 
Table 1 Revenue Inequality Among the Approximately Top 150 Athletic Programs, 1962-1997

\begin{tabular}{lc}
\hline Year & Top School/Average School \\
\hline 1962 & 1.81 \\
1970 & 1.92 \\
1980 & 2.48 \\
1989 & 3.04 \\
1995 & 3.29 \\
1997 & 3.48 \\
\hline
\end{tabular}

Note. Sources: Mitchell Raiborn, Financial Analysis of Intercollegiate Athletics. Kansas City: NCAA, 1970; M. Raiborn, Revenues and Expenses of Intercollegiate Athletic Programs, 1970-1977, 1978-1981, 1981-1985, 1985-1989. Overland Park: NCAA, 1978, 1982, 1986, 1990; Daniel Fulks, Revenues and Expenses of Intercollegiate Athletic Programs, 1993. Overland Park: NCAA, 1994; D. Fulks, Revenues and Expenses of Division I and II Intercollegiate Athletic Programs, 1995, 1997. Overland Park: NCAA, 1996, 1998.

It is also noteworthy that the Supreme Court ruling was largely coincident with the explosion in popularity of cable television in the United States. Whereas in 1980 there were 15.5 million cable TV homes (or 19.9\% of TV households), by 1990 there were 52 million cable TV homes (or 56.4\% of TV households). As is well known, cable television adds a second revenue stream (monthly subscription fees) to the traditional advertising stream, and, hence, its expansion helps to explain the rapid growth in television contracts for the elite football conferences in Division I.

\section{Bowl Championship Series}

Another factor promoting inequality is the existence of the Bowl Championship Series (BCS) within the Football Bowl Subdivision (FBS). The BCS is presently being restructured for 2015 . However, its new form has not been fully decided or, at least, if it has, only partial information has been publicly revealed as of January 2013 (see McMurphy, 2012; Myerberg, 2012). Since its inception in 1998 through 2014 , it has allowed for preferential bowl access and sharply differential revenues to flow to the six original BCS (aka, automatic qualifier or AQ) conferences.

Overall, during the first thirteen years of the system, BCS bowls have included 105 appearances by AQ conference teams and only seven appearances by non-AQ conference teams. As seen in Table 2, during 2007-2011, total payouts from the BCS bowls amounted to $\$ 722.1$ million, of which $\$ 618.4$ million (or $85.6 \%$ ) has gone to AQ conferences.

\section{NCAA Distributions}

In 2011-12, the NCAA redistributed \$467 million to Division I schools (see Table 3 ); that is, the Association distributed $61 \%$ of its revenues to $32 \%$ of its schools. The six elite conferences within the FBS of Division I received approximately $48 \%$ 
of the total revenue disbursement. These six conferences represented 73 schools, accounting for $21.5 \%$ of Division 1 schools and only $6.9 \%$ of all NCAA members. The nonelite conferences received the other $52 \%$. The nonelite conferences represent 267 schools, $78.5 \%$ of Division I schools. Division II (with $26.5 \%$ of the NCAA's schools) received $4.37 \%$ of NCAA revenues (or $6.4 \%$ of distributions) and Division III (with $41.5 \%$ of schools) received $3.18 \%$ (or $4.6 \%$ of distributions).

Of course, it may be argued that Division I schools generate almost all of the NCAA's revenue and, therefore, they are entitled to a disproportionate share of the revenue. Still, if the NCAA is trying to promote balance on the playing fields, amateurism, and the primacy of education, as it claims; then a more equal distribution of revenues would better suit these goals.

Table 2 BCS Revenue Distribution by Conference

\begin{tabular}{lcc}
\hline Conference & $\mathbf{2 0 0 9 - 1 0}$ & $\mathbf{2 0 1 0}-\mathbf{1 1}$ \\
\hline Big 10 & $\$ 22.2$ million & $\$ 27.2$ million \\
SEC & $\$ 22.2$ million & $\$ 27.2$ million \\
ACC & $\$ 17.7$ million & $\$ 21.2$ million \\
Big 12 & $\$ 17.7$ million & $\$ 21.2$ million \\
Big East & $\$ 17.7$ million & $\$ 21.2$ million \\
Pac 10 & $\$ 17.7$ million & $\$ 27.2$ million \\
Notre Dame & $\$ 1.3$ million & $\$ 1.6$ million \\
Total AQ & $\$ 116.5$ million & $\$ 146.8$ million \\
MWC & $\$ 9.8$ million & N/A \\
WAC & $\$ 7.8$ million & N/A \\
C-USA & $\$ 2.8$ million & N/A \\
MAC & $\$ 2.1$ million & N/A \\
Sun Belt & $\$ 1.5$ million & N/A \\
Total Non-AQ & $\$ 24.0$ million & $\$ 24.7$ million \\
\hline
\end{tabular}

Table 3 NCAA Revenue Distributions, 2011-12

\begin{tabular}{lcccc}
\hline & \# Schools & \% Schools & Millions \$ & $\%$ Distribution \\
\hline Division I & 340 & $32.0 \%$ & $\$ 467$ & $89.00 \%$ \\
AQ & 73 & $6.9 \%$ & $\$ 224.2$ & $42.70 \%$ \\
Non-AQ, FCS, NFS & 267 & $25.1 \%$ & $\$ 242.8$ & $46.30 \%$ \\
Division II & 282 & $26.5 \%$ & $\$ 33.5$ & $6.40 \%$ \\
Division III & 442 & $41.5 \%$ & $\$ 24.3$ & $4.60 \%$ \\
\hline
\end{tabular}


The skewed revenue distribution is mirrored by the NCAA's power structure, which leans heavily toward representation from Division I, and within Division I, heavily toward the FBS. The NCAA Executive Committee carries the deciding vote regarding policy issues affecting the entire Association. This Committee consists of 16 voting members and 4 nonvoting members. Of the 16 voting members, 8 are chancellors or presidents from FBS institutions. The remainder of the Executive Committee is a smattering of smaller Division I football programs, as well as Division II and Division III chancellors or presidents.

The Division I Board of Directors sets Division I policy. It consists of 11 FBS presidents and 7 non-FBS presidents (who rotate among the 20 non-FBS conferences.) Thus, FBS, with 120 schools, has $61 \%$ of the voting power on the Division I Board, despite the fact that it represents only $36 \%$ of the 340 schools in Division I. Of the 11 FBS representatives, 6 representatives and the chair of the Board come from the six elite (or AQ) conferences within FBS. The Division I Leadership Council is responsible for advising the Division I Board of Directors, overseeing the appointment and substructure of cabinets and committees, and taking final action on matters delegated to it by the Board of Directors. The Leadership Council is comprised of 31 members, one from each conference. However, the amount of voting power differs by conference. Representatives from the six elite conferences and Conference USA each receive three votes. The other 4 remaining FBS conference representatives each receive 1.5 votes. The 20 non-FBS conference representatives each receive 1.2 votes. Thus, the FBS conferences have a combined 27 votes while the non-FBS conferences have 24 .

The Division I Legislative Council has the same structure as the Leadership Council. The FBS conferences have the majority of the votes. The Legislative Council is the primary legislative authority. It is in charge of developing educational material regarding pending legislation. While the objective is equity, the structure of the governing NCAA committees reveals a bias toward prominent football institutions from the elite conferences.

\section{Digital TV, the Internet and Conference-Based Networks}

The advance of the digital age has allowed for the multiplication of specialized television programming. Part of the consequent channel proliferation has been in regional sports networks. Sports programming has grown more popular not only with the culture's increasing fascination with sport, but also with the rapid introduction of the digital video recorder (DVR) which allows, at the click of a button, the recording of television shows and their replay at a later time without commercials. Since sports fans generally want to watch their sports live, while TV dramas, sitcoms, and other programming are not time sensitive and can be watched hours or days later without any, or only a minimal, sacrifice of viewing enjoyment, advertisers are showing a heightened interest in sports. This has driven the demand for new regional sports networks (RSNs) upward, just as the institutional uncertainty engendered by Internet streaming possibilities has whetted the appetite of cable distribution companies and networks to own sports programming. The result has been twofold: (a) rapidly rising rights fees and (b) joint ventures between media companies and college sport conferences to form RSNs. 
The Big Ten Conference and the Fox Entertainment Group created the first such RSN in 2007. Today, the Big Ten Network (BTN) reaches over 40 million households across the U.S. and Canada and shows over 360 Big Ten live sporting events each year. BTN generally carries the less competitive and less popular conference football and basketball games, as well as games from the "non-revenue" sports, allowing the Big Ten to sell the TV rights to the networks for its most valuable contests. Nevertheless, BTN charges distributors as much as 90 cents per month per subscriber and pays out over \$6 million to each Big Ten school annually. Between BTN and national network contracts, the Big Ten is able to distribute some \$25 million television dollars to each school per year. BTN has created a mobile app called BTN2Go. For a fee it will be available to fans and alumni throughout the world.

Attempting to broaden its geographical reach and to expand to 12 members, which enables a split into two divisions and a conference playoff game, the Big Ten announced in December 2009 its intention to add an additional member. This announcement kicked off a second wave of conference realignments.

Shortly after the Big Ten's intention was made public, the Pac-10 announced similar plans. On June 7, 2010 the Pac-10 issued invitations to Colorado, Oklahoma, Oklahoma State, Texas, Texas A\&M, and Texas Tech to join its conference. On June 9, 2010, it was announced that Nebraska would enter the Big Ten, engendering uncertainty about the future of the Big 12 Conference. The next day Colorado accepted the Pac-10's invitation, while the other schools opted to remain in the Big 12. In the cases of Texas and Oklahoma, however, the schools were able to negotiate privileged status, putting new strains on the conference. Utah accepted a Pac-10 invitation on June 17, 2010. These machinations in the Big Ten and Pac-10 created reverberations first in the Big 12, and as the Big 12 began to shake, then so did the other FBS conferences. The earth was moving under the each school's feet and an urgent need to find the most solid and lucrative conference deal led program after program to shift conferences.

BTN's remarkable initial success, together with the new opportunities opened up by the digital revolution, inspired other schools and conferences to maximize the new media revenue opportunities. The Pac-12 started its own RSN, with regional subsidiaries, and signed a deal with ESPN and Fox averaging \$21 million per school per year. The Big 12 also signed a deal with ESPN and Fox for \$2.6 billion over 13 years (or \$20 million per school per year.) In May 2012, the ACC restructured its TV deal with ESPN, which will be worth $\$ 17.1$ million per school annually, once Pittsburgh and Syracuse officially join the conference. In June 2012, the SEC signed a new, 15-year TV deal with ESPN and CBS that will provide an average of $\$ 19.5$ million per school annually and allow for the possible launching of an SEC RSN in 2014.

The merger and acquisition phase of college conferences is still active as I write in early 2013. The Western Athletic Conference, having lost its football powerhouses, has declared that it will no longer play football. The Big East is now eviscerated, having lost its strongest football and basketball schools. Generally, the old and new members of the Big Ten, the Pac-12, the SEC, the ACC and the Big 12 will benefit financially, at least in the near future, from these developments. The other FBS schools will find their relative financial position diminished. To no one's surprise, the rich will get richer and the poor will get poorer. Below I turn to consider the available data on revenue inequality in college sports since 2000 . 


\section{Revenue Inequality Since 2000}

Revenue distribution data before 2000 is scarce, and that which is available is generally tabulated with different metrics than what is available since 2000. It is therefore difficult to get an accurate picture of how much inequality has increased over the decades. Further, due to inconsistent and incomplete accounting practices within athletic departments and the fact that a good deal of revenue and cost information is treated as proprietary, it is impossible even today to achieve a full and accurate picture of the extent of inequality. Nonetheless, it is possible to compile pieces of information from the periodic NCAA Revenues and Expenses reports (Fulks, 2005, 2008, 2011), the EADA reports (http://ope.ed.gov/athletics/), and other sources to assemble a broad outline of the trends and the status quo in revenue inequality among FBS programs.

In Table 1, we presented data on the highest to average revenue ratio for roughly the top 150 athletic programs between 1962 and 1997. It depicted a clear trend toward greater inequality with some acceleration in the trend after the 1984 Supreme Court decision. The post-2003 data are for the FBS (120 schools in 2010-11) and it refers to the highest to the median revenue ratio. With the skewed revenue distribution that prevails in the FBS, the mean will typically be considerably above the median, so these two data series are not comparable.

Although the top/average revenue ratio series ends in 1997, it is possible to extend the trend through 2003 by reference to NCAA data for football and men's basketball programs. Table 4 shows that the ratio of the highest revenue program from football and men's basketball to the average revenue program steadily increased from 3.56 in fy1997, to 3.66 in fy 1999 and to 3.89 in fy2003.

After 2003, the average program is no longer reported; only the median is reported. As shown in Table 5, the ratio of the highest to median school for football and men's basketball revenue continues its steady ascent between fy2004 and fy 2010 .

Table 4 FBS Football and Men's Basketball Revenue, 1997-2003

\begin{tabular}{lccc}
\hline & High & Average & Ratio (high/avg) \\
\hline 1997 & $\$ 37,400,000$ & $\$ 10,500,000$ & 3.56 \\
1999 & $\$ 44,700,000$ & $\$ 12,200,000$ & 3.66 \\
2003 & $\$ 67,300,000$ & $\$ 17,300,000$ & 3.89 \\
\hline
\end{tabular}

Table 5 FBS Football and Men's Basketball Revenue, 2004-2010

\begin{tabular}{cccc}
\hline & High & Median & $\begin{array}{c}\text { Ratio } \\
\text { (high/median) }\end{array}$ \\
\hline 2004 & $\$ 62,708,000$ & $\$ 11,501,000$ & 5.45 \\
2007 & $\$ 89,379,000$ & $\$ 15,740,000$ & 5.68 \\
2010 & $\$ 119,833,000$ & $\$ 20,986,000$ & 5.71 \\
\hline
\end{tabular}


From 2004 forward, the highest to median total program revenue is also available. Table 6 depicts this ratio, along with the top to median expenditure ratio, for 2004 and 2010. These total revenues include both generated revenues and allocated revenues from the university or state government. Since the lower revenue programs receive more university and government subsidies, the inequality in generated revenues is considerably higher than in total revenues. In 2010, the ratio of top to median generated revenues was 4.07.

It is important to note that the top/median expense ratio is lower than that of the top/median revenue ratio and that it falls between 2004 and 2010, even as the ratio grows for revenue. As revenues grow more unequal in FBS, costs are leveling, suggesting that certain program costs are sticky and that the lower revenue programs are accelerating spending in an effort to catch up to the successful ones. This pattern is consistent with the growing operating deficits of the average program, as depicted in Table 7.

Also note that the top/median revenue ratio, while still increasing, has basically leveled off. This is indicative of a general pattern over the last ten years wherein relative inequality is stabilizing while absolute inequality continues to grow significantly.

The numbers in Table 7 indicate that the median FBS program lost over $\$ 11$ million on an operating basis in fy 2010 , almost double its losses in fy2004. It is important to underscore that these losses do not include the bulk of capital costs which one study commissioned by the NCAA estimated could exceed \$20 million a year at a typical FBS institution (Orszag \& Orszag, 2005)

Another view of revenue inequality by deciles in the FBS is provided in Table 8. Although the two years are not neatly comparable because the fy 2003 data are for total revenues and the fy 2010 data are for generated revenues, there is an apparent trend toward greater inequality. The standard deviation of the revenue more than doubles between the two years.

Yet another perspective on growing inequality is shown in Table 9, which reports on revenue distribution across FBS conferences, with emphasis on the automatic qualifying (AQ) and nonautomatic qualifying (non-AQ) conferences.

Table 6 FBS Total Athletic Program Ratios

\begin{tabular}{lcc}
\hline & Top/Median Revenue & Top/Median Expense \\
\hline 2004 & 3.72 & 3.11 \\
2010 & 3.74 & 2.79 \\
\hline
\end{tabular}

Table 7 FBS Net Revenue on Operating Basis

\begin{tabular}{lll}
\hline & Highest & Median \\
\hline 2004 & $\$ 13,774,000$ & $-\$ 6,127,000$ \\
2010 & $\$ 13,118,000$ & $-\$ 11,352,000$ \\
\hline
\end{tabular}


Table 8

FBS Men's Total Revenues, 2003

\begin{tabular}{|c|c|c|c|}
\hline Percentile & More than & Less Than & Range Avg \\
\hline $0-10$ & $\$ 1,145,000$ & $\$ 2,700,000$ & $\$ 1,922,500$ \\
\hline $11-20$ & $\$ 2,700,000$ & $\$ 5,200,000$ & $\$ 3,950,000$ \\
\hline $21-30$ & $\$ 5,200,000$ & $\$ 7,400,000$ & $\$ 6,300,000$ \\
\hline $31-40$ & $\$ 7,400,000$ & $\$ 11,200,000$ & $\$ 9,300,000$ \\
\hline $41-50$ & $\$ 11,200,000$ & $\$ 15,700,000$ & $\$ 13,450,000$ \\
\hline $51-60$ & $\$ 15,700,000$ & $\$ 20,800,000$ & $\$ 18,250,000$ \\
\hline $61-70$ & $\$ 20,800,000$ & $\$ 26,000,000$ & $\$ 23,400,000$ \\
\hline $71-80$ & $\$ 26,000,000$ & $\$ 31,500,000$ & $\$ 28,750,000$ \\
\hline $81-90$ & $\$ 31,500,000$ & $\$ 41,000,000$ & $\$ 36,250,000$ \\
\hline \multirow[t]{2}{*}{$91-100$} & $\$ 41,000,000$ & $\$ 68,000,000$ & $\$ 54,500,000$ \\
\hline & & $\mathrm{SD}$ & $\$ 16,577,883$ \\
\hline \multicolumn{4}{|c|}{ FBS Total Generated Revenues, 2010} \\
\hline Percentile & More than & Less Than & Range Avg \\
\hline $0-10$ & $\$ 3,820,000$ & $\$ 6,083,000$ & $\$ 4,951,500$ \\
\hline $11-20$ & $\$ 6,084,000$ & $\$ 8,294,000$ & $\$ 7,189,000$ \\
\hline $21-30$ & $\$ 8,295,000$ & $\$ 13,281,000$ & $\$ 10,788,000$ \\
\hline $31-40$ & $\$ 13,282,000$ & $\$ 22,973,000$ & $\$ 18,127,500$ \\
\hline $41-50$ & $\$ 22,974,000$ & $\$ 35,365,000$ & $\$ 29,169,500$ \\
\hline $51-60$ & $\$ 35,366,000$ & $\$ 44,330,000$ & $\$ 39,848,000$ \\
\hline $61-70$ & $\$ 44,331,000$ & $\$ 57,615,000$ & $\$ 50,973,000$ \\
\hline $71-80$ & $\$ 57,616,000$ & $\$ 71,093,000$ & $\$ 64,354,500$ \\
\hline $81-90$ & $\$ 71,094,000$ & $\$ 97,715,000$ & $\$ 84,404,500$ \\
\hline \multirow[t]{2}{*}{$91-100$} & $\$ 97,716,000$ & $\$ 143,555,000$ & $\$ 120,635,500$ \\
\hline & & $\mathrm{SD}$ & $\$ 37,784,11$ \\
\hline
\end{tabular}

Considering football and men's basketball revenue together, the standard deviation of revenue distribution by conference increased sharply from $\$ 144.0$ million in 2003 to \$237.4 million in 2010. Further, separating FBS into AQ and non-AQ conferences, Table 8 shows that the difference in the average total revenue of $A Q$ and non-AQ conferences grew from $\$ 243.7$ million in 2003 to $\$ 387.3$ million in $2010 .{ }^{5}$

The familiar virtuous cycle or positive feedback loop is working here: strong teams lead to high attendance and television revenues, which provides the resources to reinforce the strong teams, and so on. Upward mobility is limited by this tight loop: of the FBS schools in the top decile of revenue generators in 2005, $80 \%$ of them remained in the top decile in 2010 (Cheslock \& Knight, 2012). 
Table 9 FBS Conference Inequality, 2003-2010

\begin{tabular}{|c|c|c|c|c|}
\hline & Conference & $\begin{array}{l}\text { Total Football } \\
\text { Revenue }\end{array}$ & $\begin{array}{c}\text { Total Men's } \\
\text { Basketball } \\
\text { Revenue }\end{array}$ & $\begin{array}{c}\text { Football + } \\
\text { Basketball } \\
\text { Revenue }\end{array}$ \\
\hline \multirow[t]{15}{*}{2003} & Atlantic Coast & $\$ 180,171,498$ & $\$ 89,947,019$ & $\$ 270,118,517$ \\
\hline & Big East & $\$ 123,255,993$ & $\$ 64,569,934$ & $\$ 187,825,927$ \\
\hline & Big Ten & $\$ 276,809,402$ & $\$ 105,113,003$ & $\$ 381,922,405$ \\
\hline & Big 12 & $\$ 258,812,764$ & $\$ 78,194,746$ & $\$ 337,007,510$ \\
\hline & $\begin{array}{l}\text { Conference } \\
\text { USA }\end{array}$ & $\$ 69,615,428$ & $\$ 29,599,122$ & $\$ 99,214,550$ \\
\hline & Mid-American & $\$ 33,280,645$ & $\$ 15,693,288$ & $\$ 48,973,933$ \\
\hline & Mountain West & $\$ 53,061,049$ & $\$ 34,001,598$ & $\$ 87,062,647$ \\
\hline & Pacific-10 & $\$ 176,744,243$ & $\$ 60,011,337$ & $\$ 236,755,580$ \\
\hline & Southeastern & $\$ 350,193,187$ & $\$ 81,250,948$ & $\$ 431,444,135$ \\
\hline & Sun Belt & $\$ 22,333,410$ & $\$ 12,182,508$ & $\$ 34,515,918$ \\
\hline & Western Athletic & $\$ 34,188,546$ & $\$ 15,283,538$ & $\$ 49,472,084$ \\
\hline & SD & $\$ 113,607,693$ & $\$ 33,294,075$ & $\$ 144,048,005$ \\
\hline & AQ avg & $\$ 227,664,515$ & $\$ 79,847,831$ & $\$ 307,512,346$ \\
\hline & Non-AQ avg & $\$ 42,495,816$ & $\$ 21,352,011$ & $\$ 63,847,826$ \\
\hline & AQ-Non-AQ & $\$ 185,168,699$ & $\$ 58,495,820$ & $\$ 243,664,519$ \\
\hline \multirow[t]{15}{*}{2010} & Atlantic Coast & $\$ 278,558,264$ & $\$ 146,638,009$ & $\$ 425,196,273$ \\
\hline & Big East & $\$ 221,618,743$ & $\$ 122,963,744$ & $\$ 344,582,487$ \\
\hline & Big Ten & $\$ 466,123,523$ & $\$ 152,852,255$ & $\$ 618,975,778$ \\
\hline & Big 12 & $\$ 431,271,998$ & $\$ 121,797,935$ & $\$ 553,069,933$ \\
\hline & $\begin{array}{l}\text { Conference } \\
\text { USA }\end{array}$ & $\$ 111,232,908$ & $\$ 56,707,091$ & $\$ 167,939,999$ \\
\hline & Mid-American & $\$ 80,508,627$ & $\$ 36,288,065$ & $\$ 116,796,692$ \\
\hline & Mountain West & $\$ 105,176,368$ & $\$ 51,528,057$ & $\$ 156,704,425$ \\
\hline & Pacific-10 & $\$ 252,858,608$ & $\$ 90,156,086$ & $\$ 343,014,694$ \\
\hline & Southeastern & $\$ 640,229,277$ & $\$ 138,777,080$ & $\$ 779,006,357$ \\
\hline & Sun Belt & $\$ 56,678,431$ & $\$ 24,526,765$ & $\$ 81,205,196$ \\
\hline & Western Athletic & $\$ 67,120,620$ & $\$ 26,709,080$ & $\$ 93,829,700$ \\
\hline & SD & $\$ 193,162,379$ & $\$ 50,359,583$ & $\$ 237,384,451$ \\
\hline & AQ avg & $\$ 381,776,736$ & $\$ 128,864,185$ & $\$ 510,640,920$ \\
\hline & Non-AQ avg & $\$ 84,143,391$ & $\$ 39,151,812$ & $\$ 123,295,202$ \\
\hline & AQ-Non-AQ & $\$ 297,633,345$ & $\$ 89,712,373$ & $\$ 387,345,718$ \\
\hline
\end{tabular}


Historically strong football programs also find it easier to maintain attendance and revenue even during poor performance years. The correlation coefficient between win percentage and attendance during 2005-2011 was .16 for AQ schools and .35 for non-AQ schools. That is, attendance at non-AQ schools was much more sensitive to team performance than for AQ schools.

Finally, Table 10 presents a breakdown in the sources of revenue inequality among the four quartiles of athletic programs in FBS in fy 2010. There are four categories of revenues that account for the lion's share of the differences between the top quartile and bottom quartile of athletic programs: ticket sales where the average difference between programs in the top and bottom quartiles is $\$ 23.3$ million; NCAA and conference distributions where it is \$18.1 million; alumni donations

\section{Table 10 Sources of Revenues Division I-FBS by Expense Quartile Fiscal Year 2010, Median Values in Current Dollars}

\begin{tabular}{|c|c|c|c|c|}
\hline & $\begin{array}{c}\text { First (High) } \\
\text { Quartile }\end{array}$ & $\begin{array}{l}\text { Second } \\
\text { Quartile }\end{array}$ & $\begin{array}{c}\text { Third } \\
\text { Quartile }\end{array}$ & $\begin{array}{c}\text { Fourth (Low) } \\
\text { Quartile }\end{array}$ \\
\hline Total Ticket Sales & $24,418,000$ & $12,704,000$ & $6,258,000$ & $1,113,000$ \\
\hline $\begin{array}{l}\text { NCAA and conference distribu- } \\
\text { tions }\end{array}$ & $19,334,000$ & $9,914,000$ & $3,661,000$ & $1,233,000$ \\
\hline Guarantees and options & 412,000 & 623,000 & 615,000 & $1,085,000$ \\
\hline $\begin{array}{l}\text { Cash contributions from alumni } \\
\text { and others }\end{array}$ & $23,616,000$ & $10,942,000$ & $5,304,000$ & $1,423,000$ \\
\hline Third Party Support & 0 & 0 & 0 & 0 \\
\hline \multicolumn{5}{|l|}{ Other: } \\
\hline Concessions/Programs/Novelties & $1,831,000$ & $1,453,000$ & 631,000 & 136,000 \\
\hline Broadcast Rights & $1,665,000$ & 83,000 & 53,000 & 0 \\
\hline $\begin{array}{l}\text { Royalties/Advertising /Sponsor- } \\
\text { ship }\end{array}$ & $6,534,000$ & $4,197,000$ & $1,399,000$ & 590,000 \\
\hline Sports camps & 557,000 & 12,000 & 15,000 & 157,000 \\
\hline Endowment/ Investment & $1,667,000$ & 653,000 & 187,000 & 60,000 \\
\hline Miscellaneous & $2,137,000$ & 788,000 & 645,000 & 250,000 \\
\hline Total Generated Revenues & $86,942,000$ & $45,404,000$ & $23,072,000$ & $6,836,000$ \\
\hline \multicolumn{5}{|l|}{ Allocated Revenues: } \\
\hline Direct Institutional Support & 0 & $4,924,000$ & $3,822,000$ & $4,730,000$ \\
\hline Indirect Institutional Support & 0 & 122,000 & 365,000 & 728,000 \\
\hline Student Fees & 0 & $1,583,000$ & $1,714,000$ & $4,891,000$ \\
\hline Direct government support & 0 & 0 & 0 & 0 \\
\hline Total Allocated Revenues & $3,380,000$ & $9,446,000$ & $11,409,000$ & $13,615,000$ \\
\hline Total All Revenues & $89,236,000$ & $57,841,000$ & $36,586,000$ & $20,567,000$ \\
\hline
\end{tabular}


where it is $\$ 22.2$ million and the category of sponsorships, advertising and royalties where it is $\$ 5.9$ million. Although some of the television money comes indirectly via the NCAA and conference distributions, the direct payment of television rights fees has only a diminutive differential of $\$ 1.7$ million. Since it is in the area of television revenue that we can expect the largest differentials in the coming years (in some cases growing to over $\$ 20$ million per school annually), the prospect for growing inequality in FBS is daunting.

Another important contrast lies in the comparison of institutional (school and government) subsidies to athletic programs. Overall, this component of athletic revenues in FBS has been growing rapidly, from $22 \%$ of total athletic revenues in fy 2003 to $34.5 \%$ in fy 2010 . These subsidies are also very unevenly distributed across the quartiles. Average subsidies per program in 2010 were $\$ 3.4$ million in the top quartile, $\$ 9.4$ million in the second quartile, $\$ 11.4$ million in the third quartile and $\$ 13.6$ million in the bottom quartile. The growing inequality is clearly painting a bleak picture for all but the top FBS programs.

\section{Analysis and Policy Options}

Why is inequality a concern? Generally, sports leagues are preoccupied with inequality because it can impede the accomplishment of two basic league goals: competitive balance and financial stability. Competitive, or playing field balance, is important because it keeps contests close and fans interested. Financial stability is important because it secures steady participation in the league by all teams. In college sports, of course, financial stability is crucial to avoid too large a drain on a university's educational budget.

The analog to competitive balance in professional sports leagues is competitive balance in athletic conferences. It is not, however, a perfect analogy, because college teams seek not only to win their conference, but also to win the national championship and throughout the season fans pay close attention to a school's national ranking. There is a parallel here to the dual goal of European soccer leagues, where teams first try to win their domestic league and then try to win the pan-European Champions League. Both the domestic and international championships are roughly equal in reputational and financial value. In European soccer leagues there is less revenue sharing, because more sharing weakens the top domestic teams and reduces their chances of victory in the European competition. A similar dynamic has limited the pursuit of equality (and, hence, revenue sharing) within FBS conferences.

Financial stability has been a growing problem throughout college sports. The median deficit in FBS athletic programs has grown steadily over the last twenty years, from $-\$ 237,000$ in fy 1995 to $-\$ 11.4$ million in fy 2010 . As the data presented earlier suggests, revenue has grown more concentrated, but cost increases have been distributed more equally throughout all FBS schools. Inevitably, this means that more and more schools will suffer growing deficits. The schools in the richest FBS conferences, however, have recently seen their media revenue increase by roughly $\$ 15$ million per year or more. The lead schools in those conferences are increasingly generating true accounting surpluses in their athletic programs. Other schools are coming closer to breaking even. 
Yet, even for those schools that are reaching a financial balance in athletics for the first time, there is a question about what the future holds. Several factors suggest that the explosion in media income may have created a bubble, including: (a) the impact of the DVR in shifting advertisers to sports; (b) the race of networks, cable and satellite distributors, and media companies to own sports programming in an uncertain institutional context; (c) the proliferation of video viewing and programming options; (d) rapidly rising cable fees in an environment of tight household budget constraints; (e) the possibility that the FCC or Congress will impose some degree of a la carte pricing; and (f) the uncertainty about programming distribution systems with the growing prominence of the internet and mobile devices. ${ }^{6}$ Given these factors, it is sensible to expect that media income will either flatten out or decrease in the coming years. In the worst case scenario, some media companies may go bankrupt as a result of overpaying for rights fees and/or a shift in the regulatory environment, leading conference media contracts to bottom out.

Both because of the large and growing deficits faced by the majority of FBS programs and because the few financially fortunate FBS programs will likely face greater money pressure going forward, it makes sense to think about financial reform. A significant force behind the cost increases in college sports in recent years is the anticipated return from winning. Policies that would engender greater equality would also blunt the financial incentive to win, which, in turn, should reduce program expenditures on coaches' salaries, recruitment, facilities, and travel, among other costs. Thus, equalizing the distribution of revenue may address both the goal of promoting greater competitive balance and the goal of containing costs. Serendipitously, it may also rebalance the scales in favor of educational attainment and intellectual growth.

While conferences could opt to share more internal revenue, most revenue inequality is between conferences. The only significant sources of extraconference revenue are the NCAA basketball tournament in March and the BCS. Greater revenue equality would have to emanate from NCAA policy either to distribute March Madness revenues more equally and/or to introduce an FBS football playoff with a more equal dispersion of those revenues than practiced under the BCS.

Importantly, revenue redistribution can accomplish the important goal of changing the incentives facing intercollegiate programs by lowering the distribution tied to commercial success and raising the distribution tied to educational success. For example, in 2011-12 the NCAA distributed \$467 million. Approximately 95\% of the NCAA's revenue comes from the March Madness Division I basketball tournament. Of the $\$ 467$ million, \$184.1 million (40\%) was distributed to schools according to their success in the basketball tournament over the previous six years, $\$ 122.7$ million (26\%) went to the scholarship fund which is distributed to schools according to the number of student-athlete grants-in-aid they give, ${ }^{7} \$ 61.4$ million $(13 \%)$ went to the sports sponsorship fund which is distributed to schools based on the number intercollegiate sports they sponsor, and \$66 million (14\%) went to the student assistance fund which primarily goes to support student financial need and preferentially is distributed to FBS schools. Thus, $\$ 368.2$ million, or $78.8 \%$ of the total NCAA distribution, is allocated according either to success in the March basketball tournament or to the size of the athletic program and its scholarships. The second largest recipient is the $\$ 122.7$ million allocated to the scholarship fund, which 
strongly favors FBS programs where 85 full football grants-in-aid are allowed. This means that money generated in the sport of basketball is going to support football programs, which appears to make neither logical nor educational sense.

Although $\$ 23.4$ million (5\% of total) in the academic enhancement fund and modest portions of the student assistance and supplemental funds go to support the education of student-athletes, none of the $\$ 467$ million is allocated according to the academic success of student-athletes or to other measures of school educational success. ${ }^{8}$ Restructuring these NCAA distributions, then, would not only be desirable from the perspective of financial solvency and blunting the incentives toward commercialism, but also from the perspective of incentivizing the schools' focus on educational outcomes. In the name of intercollegiate athletic integrity, the NCAA passed in late October 2012 new measures to sternly penalize transgressions and abuses in athletic programs. Reforming NCAA distribution policy would be a logical next step in this direction. Of course, the skewed voting and control patterns that prevail in the NCAA's decision-making bodies are likely to impede such progress.

Another way to deal with financial imbalances in intercollegiate programs is for the NCAA to legislate cost containment. The difficulty with this approach is that it is bound to run afoul of the nation's antitrust laws. To be sure, the easiest route to equalizing the distribution of revenue-a national NCAA football television contract-bumps up against the same constraint. The obvious answer is to have the U.S. Congress carefully craft a limited antitrust exemption for the NCAA that would allow the Association to control coaches' compensation, cartelize the national television contract, limit recruiting expenditures, the number of coaches per team and the number of games per sport per season, and perhaps a few other things. This exemption could be granted in exchange for the NCAA organizing the national FBS football championship and following a more equal distribution of its March Madness and other central revenues.

Of course, this is easier said than done. The NCAA's governing structure is effectively controlled by the AQ schools within FBS and even if this were not the case, the strong revenue producers could threaten to pull out of the Association. Were it bold and forward looking, Congress has another lever it could pull: threaten to end the tax privileges and workmen's compensation status of any programs that do not submit to the NCAA's new redistribution program, or to the entirety of the NCAA membership if the NCAA does not undertake said program.

Mobilizing the political support for such a reform will not be easy. What is different today than in the past is that the financial condition of U.S. colleges and intercollegiate athletics, and that state fiscal budgets that support them, are much shakier than ever before. College presidents and governing boards are compelled to pay attention to serious reform efforts that will moderate financial imbalances. The Knight Commission survey of FBS presidents in 2009 suggested a deeper concern and greater openness to real reform.

The intent of the reforms outlined above is to preserve and strengthen intercollegiate athletics by putting them on a sounder and more equitable financial footing. They would also promote the proper role of athletics in U.S. higher education. Whether these or similar reforms come to fruition will depend upon the organizational effort and skill that are put behind them. One thing is certain: If reform-minded presidents and governing boards give up before they begin, then no productive change will result. 


\section{Notes}

1. This limit was increased to three in the NCAA's 1981 contract with the networks.

2. The portion of the rights fee retained by the participating school varied, depending on conference revenue sharing rules.

3. For an excellent and detailed discussion of the legal arguments in this case, see Brian Porto, The Supreme Court and the NCAA. Ann Arbor: University of Michigan Press, 2012, ch. 3.

4. This result is consistent with economic theory. The monopolist produces to the left of the point of unitary elasticity on the demand curve. The competitive industry may produce to the right of the point of unitary elasticity, especially if marginal costs rise slowly. The only significant marginal cost to the colleges from broadcasting an extra game is the possibility that gate attendance will be hurt. These costs are presumably sufficiently low that the competitive industry may produce further to the right of unitary elasticity than the monopoly was to the left of this point (assuming the total revenue curve has a zero second derivative with respect to output, i.e., a linear marginal revenue curve.). If this is the case, then total revenues may be lower for the competitive industry. In addition to the revenues from post-1984 network contracts cited in the text, many schools and conferences entered into local and regional television deals. The number of televised contests, therefore, expanded appreciably. Rights fees from these local deals, however, were small and did not compensate for the network shortfall.

5. Another measure of inequality is provided by the Thiel Index which increased by $7.1 \%$ (from .310 to .332 ) between fy 2005 and fy 2010 among FBS programs. The Thiel Index goes from 0 (perfect equality) to 1 (perfect inequality). See also Cheslock and Knight (2012).

6. It is also relevant to observe that there are some signs of weakness in the ratings for the Pac-12 and Big 10 networks, and the Big 10 strategy to annex the media markets of New York City and Washington, D.C. markets with the addition of Rutgers and Maryland may yield significant disappointment.

7. The scale is nonlinear, so that a school granting 80.48 athletic scholarships would receive a check from the NCAA for $\$ 31,874$, while a school granting 242.44 scholarships would receive $\$ 717,805$, i.e., that latter school grants three times as many scholarships but receives 22.5 times as much aid under this NCAA fund! That is, the big-time football programs with 85 football scholarships are heavily favored by this regressive distributional scheme. Data for this discussion is from the NCAA, 2011-12 Revenue Distribution Plan.

8. Although it appears little more than tokenism, it is at least noteworthy that one of the distribution policy details the new BCS playoff structure has revealed is the intention to make ten percent of the television revenue distribution contingent on the schools meeting a specified APR threshold. The threshold itself has not yet been set. Thus, although the link between distribution and academic success appears to be rather exiguous, it is noteworthy that the BCS has gone a step beyond the NCAA in at least recognizing the significance of this nexus.

\section{References}

Byers, W. (1995). Unsportsmanlike conduct: Exploiting college athletes. Ann Arbor, MI: University of Michigan Press.

Cheslock, J., \& Knight, D. (2012). Following a problematic, yet predictable, path: The unsustainable nature of the intercollegiate athletics system. Available online at http:// www.knightcommission.org/recent-news/777-october-9-2012-governing-impact-ofhigh-financial-stakes-in-college-sports-highlighted-at-knight-commission-meeting.

Dunnavant, K. (2004). The fifty-year seduction: How television manipulated college football, from the birth of the modern NCAA to the creation of the BCS. New York: Thomas Dunne Books. 
Fulks, D. (2005). NCAA revenue and expenses report, 2002-2003. Indianapolis: National Collegiate Athletic Association.

Fulks, D. (2008). NCAA revenue and expenses report, 2004-2006. Indianapolis: National Collegiate Athletic Association.

Fulks, D. (2011). NCAA revenue and expenses report, 2004-2010. Indianapolis: National Collegiate Athletic Association.

Lawrence, P.R. (1987). Unsportsmanlike conduct: The NCAA and the business of college football. New York: Praeger.

McMurphy, B. (2012, November 13). Six bowls in playoff format. ESPN. Retrieved from http://espn.go.com/college-football/story/_/id/8624387/six-bowls-pool-collegefootball-semifinal-games

Myerberg, P. (2012, November 21). ESPN buys rights to televise new FBS playoffs. USA Today. Retrieved from http://www.usatoday.com/story/gameon/2012/11/21/espnreaches-deal-broadcast-fbs-playoff/1720001/.

Orszag, J., \& Orszag, P. (2005). The physical capital stock used in collegiate athletics: Report to the NCAA. Available online at: http://216.197.120.83/webdocs/91.pdf.

Porto, B. (2012). The Supreme Court and the NCAA. Ann Arbor: University of Michigan Press.

Sack, A.L., \& Staurowsky, E.J. (1998). College athletes for hire: The evolution and legacy of the NCAA amateur myth. Westport, CT: Praeger Press.

Smith, R.A. (1994). Television, antitrust law, and the conflict between home rule and a national NCAA policy, 1993-1994. Unpublished manuscript.

Zimbalist, A.S. (2001). Unpaid professionals: Commercialism and conflict in big-time college sports. Princeton, NJ: Princeton University Press. 